\title{
THE INFLUENCE OF HERBAGE UTILIZATION ON PASTURE PRODUCTION AND ANIMAL PERFORMANCE
}

\author{
M. L. Smetham \\ Lincoln College, Canterbury
}

Abstract

An attempt is made to establish a relationship between herbage utilization, pasture production, and animal performance per unit area. When pastures are rotationally grazed, it appears that the highest pasture yield and animal production per unit area will result only if feed demand is closely matched with supply so that little stubble is left after grazing. Experimental data indicate that the aim should be to achieve at least $60 \%$ single grazing utilization of the total herbage on offer as long as in so doing overgrazing does not occur. Future work is likely to show the need for an even greater degree of utilization if per-hectare production is to be maximized. Limited data suggest that overgrazing of ryegrass pastures commences when they are grazed below $2 \mathrm{~cm}$, while with more upright grass species this starts when defoliation is closer than $10 \mathrm{~cm}$.

\section{INTRODUCTION}

IN THE 1950s research findings were published (Brougham, 1956; Watson, 1956) which indicated that pastures regrow at a maximum rate, and yield best only when a substantial leaf area is left after grazing or cutting. However, subsequent work has shown that the repeated application of this practice of lax grazing results in neither maximum pasture, nor maximum animal production.

This review discusses this and other relevant work with the objectives, of providing guidelines on how close pastures should be grazed.

\section{CLOSENESS OF, AND INTERVAL BETWEEN GRAZING}

Woodman and Norman (1932), Lynch and Mountier (1954), Brougham (1959), and others have demonstrated that ryegrass pastures produce more if spelled for a loag rather than a short interval. Other pasture cutting (Reid, 1966; Clark et al., 1974), and cutting and grazing (Frame and Hunt, 1971) experiments have shown that, in addition to long spells, cutting or grazing to 2.5 or $3 \mathrm{~cm}$ gives higher herbage yield than mot-e lenient de- 
TABLE 1: THE RELATIONSHIP BETWEEN GRAZING PRESSURE, RESIDUAL STUBBLE YIELD AND PASTURE

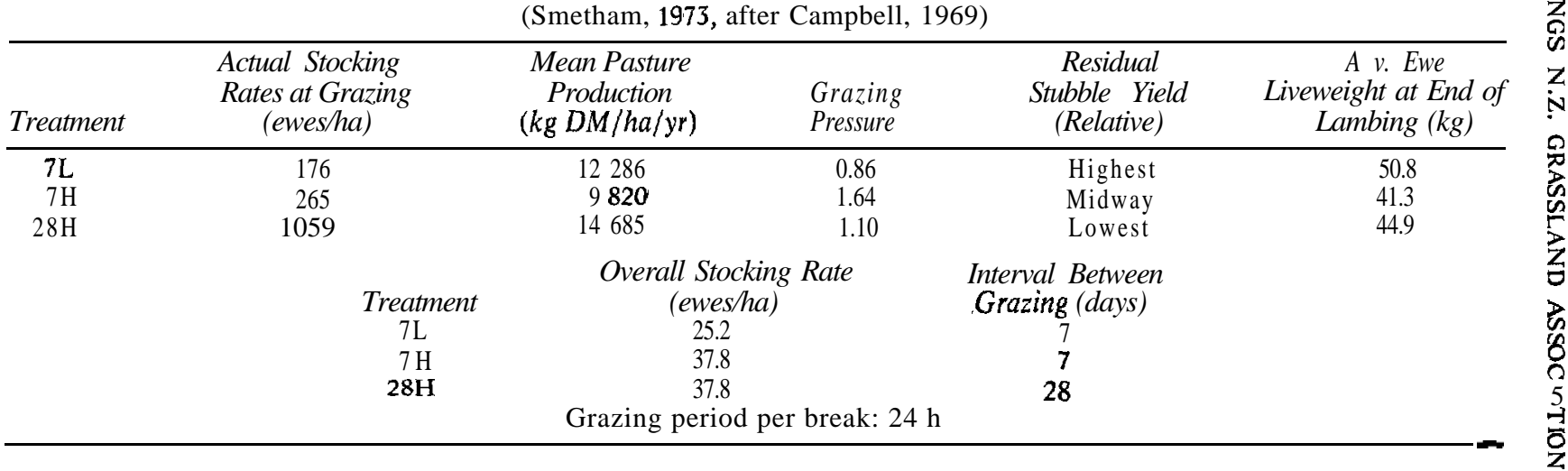


foliation. Brougham (1960) did demonstrate yield advantages from lax grazing in summer, but at other times of the year close grazing promoted the highest yields. Whilst published work does give a guide as to the actual length of spell giving maximum yield of dry matter (DM) (Brougham, 1959; Alberda, 1968; Wilman, 1975), there are few data to indicate the degree of closeness which promotes highest yield. The concept and study of grazing pressure does, however, help to provide an answer.

\section{GRAZING PRESSURE AND PASTURE PRODUCTION}

Matt (1960) and Campbell (1966b) have both expressed the relationship between stocking rate and pasture production as "grazing pressure". This was defined by Mott as the "numbers of animals per unit of available forage" and by Campbell as the "number of stock grazing days per unit of "available forage". The relatioaship is basically the requirement by the animals for feed, compared with the ability of the pasture to supply this at a given instant in time. Normally this has been calculated at the start of grazing of a fresh break in rotationally grazed systems. It is, as Campbell1 (1966b) states, "an assessment of the potential severity of defoliation". The great value of this measure - "grazing pressure" (GP) - is that it indicates the stress under which both pastures and animals are operating; something which mere mertion of stocking rate: by itself does not do.

Calculation of the mean grazing pressure for the start of each daily grazing in Campbell's (1969) self-contained farmlet experiment (Table 1, Smetham, 1973) shows that herbage yield was greatest where the grazing pressure was closest to one, at 1.1, and least when the grazing pressure was furthest away from one, at 1.64. In other words, the combination of a 28-day spell with the inevitable associated close grazing during the grazing period provided the sheep with almost exactly the amount of feed required per day. On the other hand, areas spelled for only seven days failed to provide enough feed for the animals. The feed demand was greater than feed supply as indicated by the GP of 1.64. These areas were in addition not so closely grazed as ewards given treatment $28 \mathrm{H}$, probably because high levels of trampling and fouling reduce 'animal intake (Smith and Boswell, 1973). Nevertheless, the stress on the pasture produced by the combination of grazing, and trampling, which is equivalent to severe defoliation (Edmond, 1963), was higher than on the other areas, and this led to the lowest herbage production, and also 
the lowest ewe body weight at the end of lambing, of any treatment in the trial. The pasture was, in fact, being overgrazed.

The question still unanswered, however, is how close can animals be allowed to graze before they are overgrazing?

\section{OVERGRAZING}

Many authors, including .Davidson and Miltharpe (1965), Booysen and Nelson (1975), Davies (1974), Wilson and Robson (1970), and Roberts and Hunt (1936), have shown that the ability of grasses to recover is progressively impaired by increasingly severe defoliation. For instance, Wilson and Robson using S.24 ryegrass found cutting below $6 \mathrm{~cm}$ (with the tillers pulled upright) reduced recovery in the four days following cutting by $25 \%$ when compared with uncut plants. Above this height, recovery was not affected. With prostrate ryegrasses in a natural attitude, $6 \mathrm{~cm}$ as defined above is probably equivalent to defoliation at a vertical height of about $2 \mathrm{~cm}$ above ground level. Roberts and Hunt (1936) cut perennial ryegrass to $1.25 \mathrm{~cm}$ every 30 days and found that this produced on average half the yield of swards cut to $2.5 \mathrm{~cm}$ : and tillering was reduced by $30 \%$. Unfortunately, there was no comparison with a control, but it would appear that production at $2.5 \mathrm{~cm}$ cutting height was near maximum. With a more upright growing plant like tall fescue, Matches (1966) found that defoliation to $2.5 \mathrm{~cm}$ every 10 days killed the plants in time, whereas when cut to $6 \mathrm{~cm}$ or $10 \mathrm{~cm}$ they survived, giving. relative yields of 45 and $100 \%$, respectively. Similarly, Knievel et al. (1971) obtained 40\% lower yields from timothy cut to $4 \mathrm{~cm}$ rather than $10 \mathrm{~cm}$. To avoid any penalty in yield, it appears then that prostrate ryegrass should not be grazed below about $2 \mathrm{~cm}$, and more upright species below about $10 \mathrm{~cm}$. Future work may prove that in spite of some yield penalty, closer grazing is desirable because loss of stubble material through senescence is reduced.

\section{UNDERGRAZING}

Whilst it is easy to understand that overgrazing reduces herbage yield, it is somewhat surprising that repeated undergrazing does so too. This result was obtained by Campbell (1969) where the grazing pressure was less than one, at 0.85 (Table 1). A recent cutting experiment on an irrigated mixed pasture in Australia (Clark et al., 1974) gave the same sort of result (Table 2). 
TABLE 2: THE EFFECT OF DIFFERENT HEIGHTS OF CUTTING ON THE DRY HERBAGE AND DIGESTIBLE ORGANIC MATTER YIELD OF IRRIGATED PASTURE , (Clark et al., 1974)

\begin{tabular}{ccc}
\hline Height of Cutting above & \multicolumn{2}{c}{$\begin{array}{c}\text { Annual Yield } \\
\text { Ground Level }(\mathrm{cm})\end{array}$} \\
& \multicolumn{2}{c}{$\begin{array}{c}\text { Mean Years }(\mathrm{kg} / \mathrm{ha}) \\
\text { (main effect) }\end{array}$} \\
& D M & DOM \\
\hline 3 & 12575 & 9275 \\
6 & 11100 & 8050 \\
10 & 10850 & 7875 \\
L.S.D. $(P<0.05)$ & 525 & 406 \\
L.S.D. $(\mathrm{P}<0.01)$ & 700 & 550 \\
\hline
\end{tabular}

Over a four-year period plots cut 11 times a season to $6 \mathrm{~cm}$ from $11 \mathrm{~cm}$ high were outyielded by those cut 14 times per season to $3 \mathrm{~cm}$ from $8 \mathrm{~cm}$ high. Campbell (1964) explains results like these as being due to the longer stubble left when grazing or cutting is lax causing reduced growth as a result of (a) shading leaves, so reducing photosynthesis; (b) obstructing light at the base of grass plants so reducing the subsequent rate of tillaring (Mitchell, 1953) ; (c) the residual leaves being older and hence photosynthetically less active (Pearce et al., 1968) ; and (d) — and this is probably the most significant mechanism - a greater proportion of the stubble dying before the next grazing.

A substantial loss of green herbage caused by senescence and decay in grazed pasture and amounting to 15 to $40 \%$ of total production has been recorded by Hunt (1971). Similarly, in a pasture trimmed to about $14 \mathrm{~cm}$ every seven days Hunt and Brougham (1967) found that 11 to $45 \%$ of the tillers died every seven days, implying a limited life of weeks rather than months for grass tillers. Brougham (1958) found 28 days ta be the average life of a white clover leaf in a regrowing pasture. With average commercial grazing intervals on rotationally grazed dairy pastures of 10 days in spring, 3 weeks in summer, and 6 to 9 weeks in winter, considerable amounts of herbage grown but not grazed may consequently be lost to the animals.

Whether or not a tiller or leaf will join the above-ground dead pool will depend on the physiological age of the unit when rejected at grazing. If old it will probably have senesced before the next grazing; if young it may not have, although it will be of lower quality — i.e., digestibility (Edie and Black, 1968). 
TABLE 3: LIVING HERBAGE HARVESTED, DEAD MATERIAL, AND GROSS AERIAL GROWTH OF A PASTURE SUBJECTED TO SIMULATED SHEEP GRAZING (Morris, 1970)

Sward Kept at Constant

Leaf Area Index

Medium

\begin{tabular}{|c|c|c|c|c|c|c|c|}
\hline & \multicolumn{3}{|c|}{$\begin{array}{l}\text { Sward Kept at Constant } \\
\text { Leaf Area Index }\end{array}$} & \multicolumn{3}{|c|}{ Cut to } & \multirow[b]{2}{*}{$S E$} \\
\hline & High & $\begin{array}{l}\text { Area Ind } \\
\text { Medium }\end{array}$ & Low & $\begin{array}{c}12 \mathrm{~cm} \\
\text { Every } 2 \mathrm{wk}\end{array}$ & Every $^{3 \mathrm{~cm}}$ & $w k$ & \\
\hline $\begin{array}{l}\left.\text { Mean yield of living herbage (dry wt } \mathrm{g} / \mathrm{m}^{\prime}\right)^{*} \\
\text { Total material which died }\left(\mathrm{dry} w \mathrm{tg} \mathrm{g} / \mathrm{m}^{2}\right) \dagger \\
\text { Gross aerial growth }\left(\text { dry wt } \mathrm{g} / \mathrm{m}^{2}\right) \dagger\end{array}$ & $\begin{array}{l}544 \\
457 \\
709\end{array}$ & $\begin{array}{l}640 \\
385 \\
703\end{array}$ & $\begin{array}{l}644 \\
331 \\
656\end{array}$ & $\begin{array}{l}584 \\
320 \\
604\end{array}$ & $\begin{array}{c}732 \\
198 \\
531\end{array}$ & $\begin{array}{l} \pm \\
\pm \\
\pm\end{array}$ & $\begin{array}{l}12.0 \\
34.0 \\
49.7\end{array}$ \\
\hline
\end{tabular}




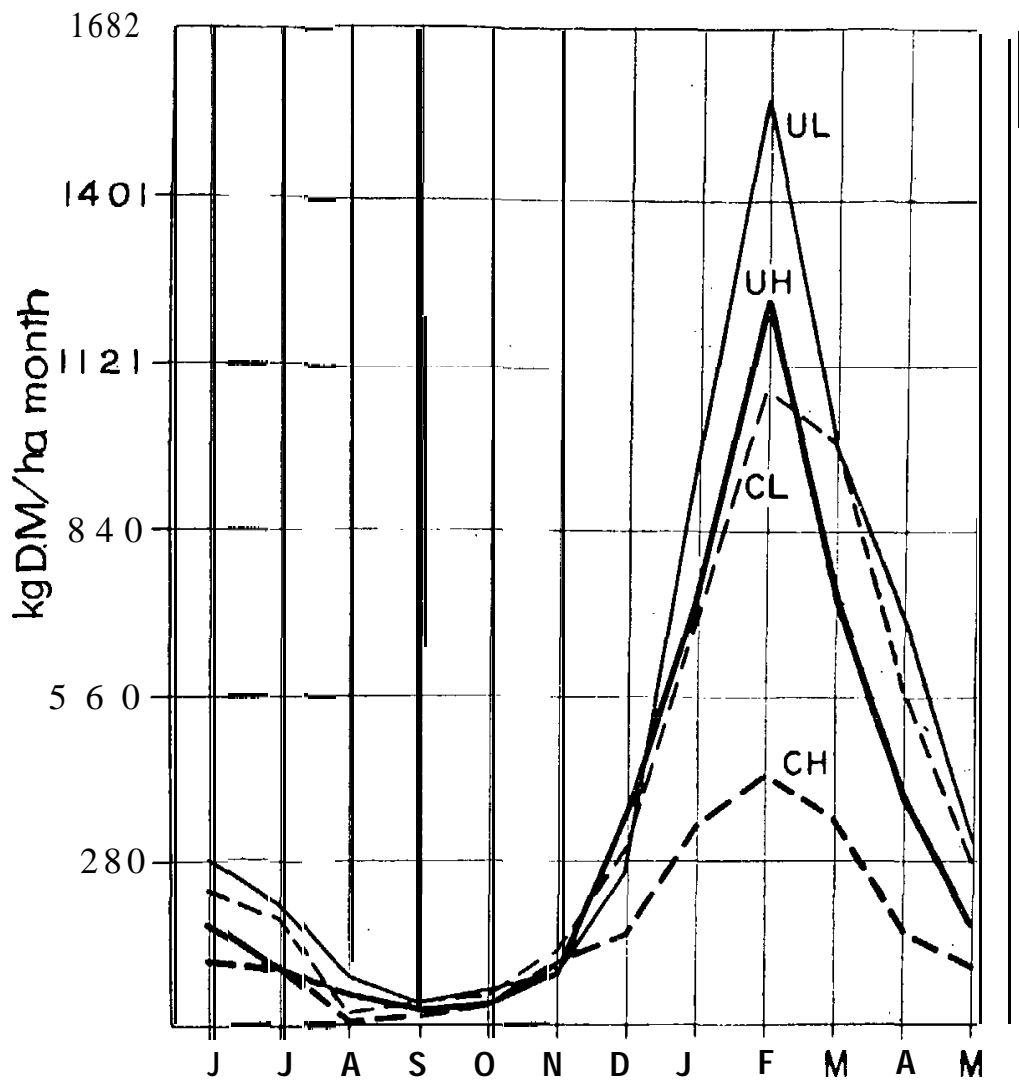

FIG. 1: Dead herbage accumulated per month in pasture grazed by cows (Campbell, 1966d).

$\mathrm{L}=2.30$ cows $/ \mathrm{ha}, \mathrm{H}=2.91$ cows $/ \mathrm{ha}, \mathrm{C}=$ rotational grazing, $\mathrm{U}=$ continuous grazing.

At all times of the year but especially in late summer, the amount of dead material (Fig. 1) in pastures poorly utilized by cows at a low stocking rate was found to be considerably greater than for cows at a higher stocking rate, according to Campbell (1966b). This result was experienced, too, by Morris (1969) who held grazed pastures at three constant but different leaf area indices in order to promote different animal carrying capacities. These did not eventuate since the higher the leaf area the more dead material built up in the canopy. In a later, experiment, Morris (1970) obtained a higher living herbage yield by cutting 
to $3 \mathrm{~cm}$ once every 4 weeks than from swards cut to $6 \mathrm{~cm}$, or those left with a predetermined leaf area. This was mainly because only half as much green material died on the close-cut areas ( $\mathrm{T}$ a b l e 3 ).

These results suggest that undergrazed pastures (achieve a balance between the degree of utilization of green material and the rate of death of leaves and tillers. This in turn affects -the rate of production of new material. In other words, the system tends to become self-limiting. This idea is supported by the results of Vickery (1972) and Birrell el al. (1974). Using Merino ewes grazing Phalaris-subterranean clover pastures, Vickery found that the net production of pastures, as measured by $\mathrm{CO}_{2}$ used, was reduced when these were over- or understocked compared with when stocking was optimum. Pastures in Victoria, Australia, were also found to produce significantly more when stocked at just the right number of animals -15 and 20 wethers/. ha, rather than 10 or 25 (Birrell et al., 1974).

Apart from any direct effect on yield, leaving a long stubble may indirectly affect yield by increasing tiller mortality. Lax grazing quickly encourages normally prostrate varieties of ryegrass to develop elevated vegetative growing points and aerial tillers, both of which make the tillers much more likely to be killed when grazed (Hughes and Jackson, 1974).

\section{UTILIZATION AND ANIMAL PRODUCTION}

The general conclusion that can be reached so far is that pastures yield best when the demand for feed is just met by the ability of the pasture to supply this - i.e., when the grazing pressure is 1.0, and there is neither over-, nor undergrazing. While close grazing promotes a higher yield than lax grazing, production wilt be reduced if it is too close.

T'ze degree of closeness doles bear some relationship to the proportion of herbage removed by grazing. Campbell (1966b) cailed this proportion "percentage utilization" and defined it as: the weight of herbage removed by grazing, as a percentage of that availatble at the start plus growth during the grazing period. The available herbage is normally measured to ground level (Parker, 1973a, b).

In terms of utilization, therefore, the general conclusion can now be expressed as follows: that pasture yield is likely to be highest when utilization during a short oae-day grazing period is high. This is clearly only true up to the point at which overgrazing starts. In addition, the absolute amount (weight or height) 
of material left after grazing will depend greatly on the total amount of growth present before grazing. Consequently, any comments as to optimum levels of utilization need to be qualified as to desirable absolute amounts of residue.

If this qualification is borne in mind, then, from the pasture point of view, the higher the degree of utilization the better. But is this also true for stock production? The data of Birrel et al. (1974), already mentioned, indicate that it may be. The highest yield of wool per hectare in this experiment did occur with highest stocking rate.

One of the few experiments to look at utilizatioa per se and its effect on animal production is that of Greenhalgh (1970) . Throughout one saasoa dairy cows were rotationally grazed on areas of known standing herbage quantity, cow numbers being adjusted to give predetermined daily herbage allowances per cow.

TABLE 4: ANIMAL PRODUCTION AND PASTURE YIELD FOLLOWING VARIOUS LEVELS OF HERBAGE UTILIZATION BY cows

(Greenhalgh, 1970)

Duration of experiment: 150 days

Grazing period: 24 hours

Average grazing interval: 25 days

\begin{tabular}{lcccr}
\hline & \multicolumn{3}{c}{ DM Offered/cow/day } \\
& 11.4 & 15.9 & 20.9 \\
\hline Stocking rate (cows/ha) & 6.77 & 5.81 & 5.44 \\
Herbage utilization (\%) & 92 & 75 & 58 \\
Net herbagrown(kg/ha & DM) & 11350 & $11 \mathbf{1 1 0}$ & 10680 \\
$\begin{array}{l}\text { Milk production (kg/ha) } \\
\text { Digestibility of herbage organic matter } \\
\text { (SE } \pm 0.40)\end{array}$ & 16250 & 14950 & 13260 \\
& $77.9 \mathrm{a}^{*}$ & $78.1 \mathrm{a}$ & $76.4 \mathrm{~b}$
\end{tabular}

*Duncan's multiple range test; means without a common letter differ significantly. (Lower case: $P<0.05$; capitals: $P<0.01$ ).

Per-hectare milk production was highest where cows utilized $92 \%$ of the herbage above mower height offered at each grazing, compared with 75 or $58 \%$ utilization (Table 4). Current feed budgeting practice in New Zealand (Parker, 1973b) involves estimates of DM above ground level, and an assessment of the utilization of the total feed on offer. Recalculation of the utilization figures from Greenhalgh (1970), using a maximum figure of $900 \mathrm{~kg} / \mathrm{ha}$ DM (Taylor and Rudman, 1966) for the weight of material below mower height, gives a mean figure of $62 \%$ single grazing utilizatioa of total available DM at the highest stocking rate. This indicates that utilization can be in the region of 60 to 
$65 \%$ for a single grazing without depressing per-hectare animal production.

The levels of single grazing utilization obtained by Campbell ( $1966 \mathrm{~b})$ were considerably lower (19 to 33\%) than those of Greenhalgh (1970) but then the highest stocking rate in Campbell's (1966a) experiment was oaly 2.99 cows / ha compared with 6.77 cows/ha in Greenhalgh's. Nevertheless, Campbell (1966c) obtained highly significant correlations between single grazing utilizatioa and animal production per unit area. Although Greenhalgh did not assess correlations, his results also suggest a significant relationship between utilization and production.

\section{UTILIZATION AND ANIMAL INTAKE}

Just how far utilization can be pushed in the interests of perhectare production is open to conjecture. Both the length and density of pasture can affect the ability of grazing animals to obtain an adequate intake of forage (Stobbs, 1973; Arnold and Dudzinski, 1969). Grazing pastures closer in order to obtain greater utilization of the hesbage on offer is eventually bound to reduce daily voluntary intake per head below maximum (Greenhalgh et al., 1966) and below the level at which the highest peranimal production is obtained.

,Woodward (1936), and Johnstone-Wallace and Kennedy (1944) report that the intake of cows was reduced when the available dry matter (ADM) above mower height was less than $1100 \mathrm{~kg} / \mathrm{ha}$ DM. Similarly, Willoughby (1959) found that the voluntary intake of DM by Merino) ewes was reduced when green pasture meastured to ground level fell below $1500 \mathrm{~kg} / \mathrm{ha}$ DM. However, the ewes lost weight only when the ADM was down to $110 \mathrm{~kg} /$ ha DM.

If, as has been suggested, $2 \mathrm{~cm}$ is accepted as a desirable height of stubble to leave after grazing, the residual material left on temperate-species dairy pastures will amount to about $900 \mathrm{~kg} / \mathrm{ha}$ DM. Taylor and Rudman (1966) measured 165 to $432 \mathrm{~kg} / \mathrm{ha}$ greea DM per $\mathrm{cm}$ in the basal layers of beef-grazed pastures; Campbell (1966b) $366 \mathrm{~kg} / \mathrm{ha} \mathrm{DM}$ per $\mathrm{cm}$ in dairy swards, and Hughes and Jackson (1974) $400 \mathrm{~kg} / \mathrm{ha}$ DM per $\mathrm{cm}$ in regularly cut areas. The exact relationship between weight and height will, however, undoubtedly differ according to species (Stobbs, 1973).

\section{OPTIMUM UTILIZATION}

In one of the few references to the subject in New Zealand literature, Parker (1973b) recommends that no mose than $40 \%$ 
of the herbage on offer should be removed in a single grazing by high producing cows, According to him, milk yield is quickly reduced by grazing below $1350 \mathrm{~kg}$ / ha DM of staading herbage in early lactation, or below $2000 \mathrm{~kg} / \mathrm{ha}$ DM later oa. In view of the results of Morris' (1970) and Greenhalgh (1970) already discussed, it seems that, even at the high levels of production being obtained $(650 \mathrm{~kg} / \mathrm{ha}$ of milk fat), and at the high stocking rate being used (4.9 cows/ha) by Parker (1973b), the cows were merely taking the top off 'the pasture, so causing the operation to proceed below potential. Although it is not stated, it can be assumed that the animals in the self-contained farm studies above (Parker, 1973b) were being fed to appetite with about $13 \mathrm{~kg}$ DM per cow per day (Greenhalgh et al., 1966) . But utilization can only be improved beyond the $40 \%$ level advocated by Parker $(1973 \mathrm{~b})$ if the inevitable decrease in voluntary intake of DM

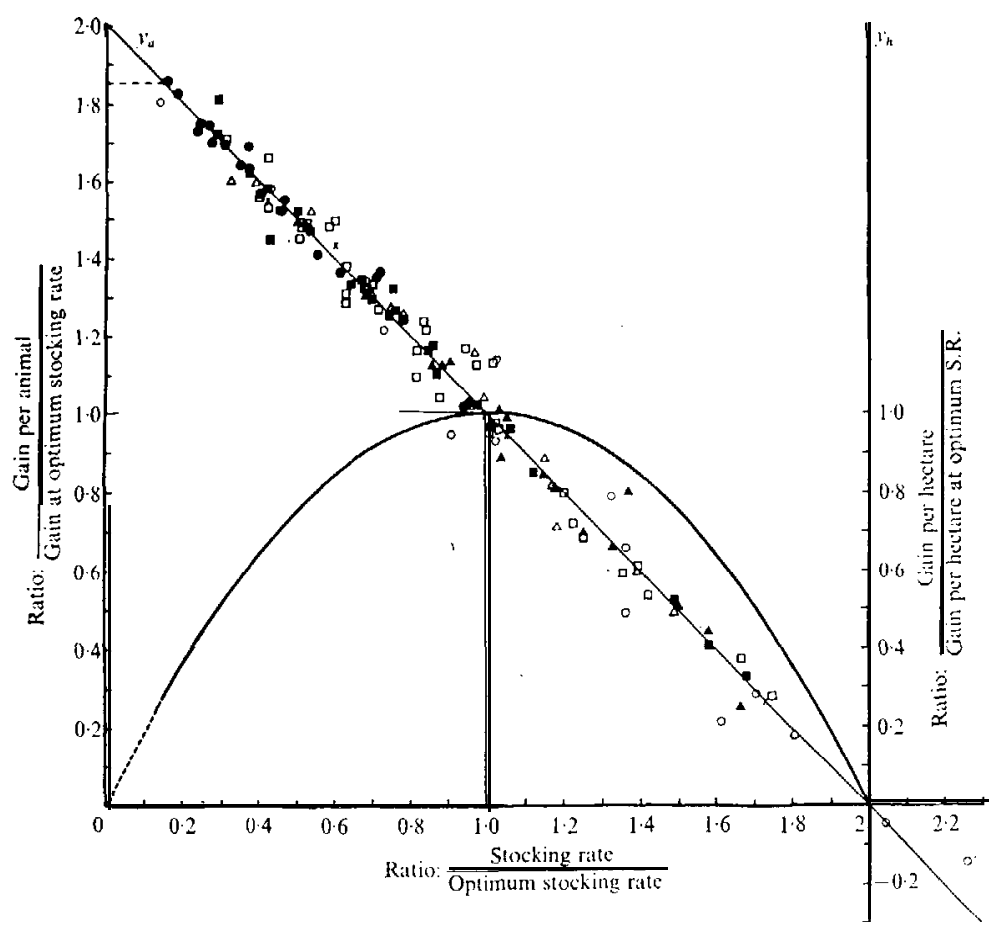

FIG. 2: The relationship between stocking rate production 1 per animal and production per hectare (Jones and Sandland, 1974). 
per cow and probable drop in production per cow are acceptable. If the stocking rate were increased accordingly, however, higher per-hectare production of milk or butterfat would result (McMeekan and Walsh, 1963).

This is entirely compatible with the movement of per-animal and per-hectare production observed in many stocking rate experiments as a result of an increase in rate (see Fig. 2). Maximum . per.hectare production results from moderately high, not the highest per-animal performance (Mott, 1960; Suckling, 1964; Jones and Sandland, 1974).

It is likely, then, that even with cows, sensitive as they are to feed quality and quantity, the aim should be single grazing utilization of better than $40 \%$ and even as high as or higher than the $62 \%$ found by Greenhalgh (1970) to give the highest production in a somewhat artificial "put and take" situation.

\section{REFERENCES}

Alberda, Th., 1968. Neth. J. agric. Sci., 16: 142-53.

Arnold, G. W.; Dudzinski, M. L., 1969. Intensive Utilisation of Pastures: 42-8. (Ed. B. J. F. James). Angus \& Robertson, Melbourne.

Birrel, H. A.; Bishop, A. H.; Cayley, J. W. D., 1974. Proc. 12th int. Grassld Congr.: 86-93.

Booysen, P de V.; Nelson, C. J., 1975. Crop Sci., 15: 262-4.

Brougham, R. W., 1956: Aust. J. agric. Res., 7: 377-87.

- 1958. N.z. Jl agric. Res., 1: 707-13.

\section{Ibid., 2: 283-96.}

1960. Ibid., 3: 125-36.

Campbell, A. G., 1964. Proc. N.Z. Soc. Anim. Prod., 24: 17-28.

1966a. J. agric. Sci., Camb., 67: 199-210.

1966b. Ibid., 67: 211-6.

- 1966c. Ibid., 67: 217-21.

1966d. Proc. 10th int. Grassld Congr.: 458-63.

1969. N.Z. Jl agric. Res., 12: 67-74.
Clark, Jennifer; Kat, C.; Santhirasegaram, K., 1974. J. Br. Grassld Soc., 29: 269-73.

Davidson, J. L.; Milthorpe, F. L., 1965. Ibid., 20: 15-8.

Davies, A., 1974. I. agric. Sci., Camb., 82: 165-72.

Edie, J., Black, J. S., 1968. In Rr. Grassld Sac. Occ. Symp. No. 4: 191-5 (ed. I. V. Hunt).

Edmond, D. B., 1963. Proc. 13th Linc. Coll. Fmrs' Conf.: 77-81.

Frame, J.; Hunt, I. V., 1971. J. Br. Grassld Soc., 26: 163-71.

Greenhalgh, J. F. D., 1970. Proc. 11th int. Grassld Congr.: 856-60.

Greenhalgh, J. F. D.; Reid, G. W.; Aitken, J. N.; Florence, E., 1966. J. agric. Sci., Camb., 67: 13-8.

Hughes, R.; Jackson, D. K., 1974. J. Br. Grassld Soc., 29: 75.

Hunt, W. F., 1971. N.Z. Il agric. Res., 14: 208-18.

Hunt, L. A.; Brougham, R. W., 1967. Ibid., 10: 397-404.

Johnstone-Wallace, D. B.; Kennedy, K., 1944. J. agric. Sci., Camb., 34: $190-7$. 
Jones, R. J.; Sandland, R. L., 1974. J. ugric. Sci., Camb., 83: 335-42.

Knievel, D. P.; Jacques, A. V. A.; Dale Smith, 1971. Agron. J., 63: 430-4.

Lynch, P. B.; Mountier, N. S., 1954. N.Z. Il Sci. Tech. 36A: 375-85.

McMeekan, C. P.; Walshe, M. J., 1963. J. agric. Sci., Camb., 61: 147-66.

Matches, A. G., 1966. Crop Sci., 6: 484-7.

Mitchell, K. J., 1953. Physiol. Plant, 6: 425-43.

Morris, R. M., 1969. J. Br. Grassld Soc., 24: 65-70.

1970. Ibid., 25: 198-206.

Mott, G. O., 1960. Proc. 8th int. Grassld Congr.: 606-11.

Parker, 0. F., 1973a: Proc. N.Z. Grassld Ass., 34 (2): 205-11.

.. 1973b: Ibid., 35 (1): 127-34.

Pearce, R. B.; Brown, R. H.; Blaser, R. E., 1968. Crop Sci., 8: 677-80.

Reid, D., 1966. J. agric. Sci., Camb., 66: 101-6.

Roberts, R. A.; Hunt, I. V., 1936. Welsh J. Agric., 12: 158-74.

Smetham, M. L., 1973. Chap. 7 In Pastures and Pasture Plants (ed. R. H. M. Langer). Reed, Wellington.

Smith, A.; Boswell, C. C., 1973. J. Br. Grassld Soc., 28: 21-6.

Stobbs, T. H., 1973. Aust. I. agric. Res., 24: 809-20.

Suckling, F. E. T., 1964. N.Z. Il Agric., 109 (2): 153-9.

Taylor, J. C.; Rudman, J. E., 1966. J. ugric. Sci., Camb., 66: 29-37.

Vickery, P. J., 1972. J. appl. Ecol., 9: 307-14.

Watson, D. J., 1956. In The Growth of Leaves (ed. F. L. Milthorpe). Butterworths, London.

Willoughby, W. M., 1959. Aust. I. agric. Res., 10: 248-60.

Wilman, D., 1975. J. Br. Grassld Soc., 30: 141-7.

Wilson, D. B.; Robson, M. I., 1970. Ibid., 25: 220-7.

Woodman, H. E.; Norman, D. B., 1932. 1. ugric. Sci., Camb., 22: 852-73.

Woodward, T. E., 1936. J. Dairy Sci., 19: 347-57. 